\title{
An Exploratory Study of Reciprocal Apple Rootstock and Scion Hardiness with Two Methods of Assessment
}

\author{
C.G. Embree and K.B. McRae \\ Agriculture Canada, Kentville Research Station, Kentville, N. S. B4N \\ 1J5, Canada \\ Additional index words. Malus domestica, root trunk hardiness
}

\begin{abstract}
Root hardiness for the apple (Malus domestica Borkh.) rootstocks M.26, MM.106, MM.111, M.7A, and M.7EMLA at - 8 and - 11C and trunk survival for the tender cultivar Gravenstein and the hardy cultivar Wealthy at $\mathbf{- 2 5}$ and $\mathbf{- 3 5 C}$ were evaluated both destructively (tissue examination) and nondestructively (regrowth measurement the following season). No differences in root survival were detected at $-8 C$ by either method; at - 11C, MM.111 rated better than the others, while regrowth was higher on M.26, MM.111, and M.7A than on MM.106 or M.7EMLA. Root survival did not differ for the scions at either temperature, but regrowth was greater for 'Gravenstein' than Wealthy' at both temperatures. Trunk tissue survival at $\mathbf{- 2 5 C}$ was consistently lowest for scions on M.7EMLA, and regrowth was less than on M.26 and MM.111. At $-35 \mathrm{C}$ there were no significant rootstock effects. For the scions, lateral wood tissue survival at $-25 \mathrm{C}$ was highest for Wealthy', but the weight of the new growth did not differ. At $\mathbf{- 3 5 C}$ bark tissue survival and regrowth was greater for Wealthy' than for 'Gravenstein'. Evidence is presented in support of the occurrence of reciprocal effects. Correlation between the two methods was highest for root exposure at - 11C and for the assessment of trunk bark.
\end{abstract}

The adaptability of Malling rootstocks to North American conditions has been questioned since the 1939 report of cold-temperature injury in New York state (Tukey and Brase, 1939). Subsequent reports of inconsistent rootstock performance in established orchards have led to the development of a hardy-rootstock breeding program (Cummins and Aldwinckle, 1974) and cooperative regional rootstock studies (Ferree and Perry, 1988). Several Malling rootstocks were among those that exhibited low-temperature injury under field (Chandler and Ferree, 1990; Simons et al., 1986; Wildung et al., 1973) and controlled conditions (Embree, 1988; Warmund and Slater, 1988). Others, such as M.26, have shown a high degree of resistance to low-temperature stress (Czynczyk, 1979; Quamme and Brownlee, 1989; Wildung et al., 1973).

Increasing the hardiness of the rootstock should improve orchard performance where root hardiness is important. It is uncertain whether scion hardiness is consistently improved by the hardiness of a rootstock. Stuart (1937) found that, following one year's growth in the nursery, the hardiness of the scion was not measurably influenced by the hardiness of the root. Other results on the reciprocal effects of scion and root hardiness are inconsistent. Filewicz and Modlibowski

Received for publication 23 Jan. 1991. We thank D.G. Baldwin for his precise technical assistance and B. Lesser for consultation during the preparation of results. The cost of publishing this paper was defrayed in part by the payment of page charges. Under postal regulations, this paper therefore must be hereby marked advertisement solely to indicate this fact.
(1941) observed that the frost-resistant cultivar Antonovka had a negative influence on the hardiness of seedling roots of fruiting trees and on M.9 roots of 1-year-old trees in a nursery. Westwood (1970) concluded that, in some cases, the influence of the scion on the root bears no relationship to the hardiness of the scion, while in other cases the effects are related. The diversity of results may be due to differences among cultivars, methods of assessing hardiness, time of testing, or other factors, such as biochemical constituents or crop load.

The purpose of this preliminary study was to compare apple root and trunk hardiness in a tender and a hardy early season cultivar on rootstocks with a range of hardiness and to determine if reciprocal transfer of hardiness occurs. Hardiness was evaluated by tissue examination in half of the trees and, in the other half, by measuring regrowth in the following season. The two methods were compared.

The hardy 'Wealthy' (Westwood, 1970) and the tender 'Gravenstein' (Embree, 1984) were grafted on the rootstocks M.26, MM.106,MM.111,M.7A, andM.7EMLA. The trees were grown in a nursery row for one summer, lifted in the fall, and placed in storage at 2 to $4 \mathrm{C}$ and $\approx 85 \%$ relative humidity. During the late winter and early spring, they were planted into 20 -liter plastic pots and positioned in a nursery row outdoors in early June. The pots were spaced at $\approx 1.5 \mathrm{~m}$, watered as required with single pressure-compensating emitters, and fertilized with a complete commercial liquid fertilizer on a regular basis until growth stopped in mid-July. The trees grew well during the summer and were moved into storage in November, before the risk of cold stress in the field.

A $3 \times 3-m$ walk-in controlled-climate chamber with $-40 \mathrm{C}$ capacity was used for the study. All treatment temperatures were imposed gradually and monitored with thermocouples positioned at several points in the chamber, on some tree trunks, and adjacent to the roots in the centers of about half the pots.

Roots of a single tree from each rootstock/ cultivar combination were exposed for $24 \mathrm{~h}$ to $-8 \mathrm{C}$, those of a second set to $-11 \mathrm{C}$, and the trunks of a third and fourth set to -25 and - 35C, respectively. Roots of trunk-exposed trees were maintained above freezing by insulating with wood sawdust and styrofoam. Immediately following treatment, the trees were returned to storage. Exposure for the first replicate of the first series commenced in mid-December, and the second replicate of the series was conducted in February. The order of the four treatments in the four replicates followed a Latin square design, exposing one tree of each replicate on each date.

Destructive evaluation. In late March and early April, trees from one of the paired replicates were inspected for symptoms of damage to the xylem, the inner bark and cambium of the trunk, and the washed roots.

Table 1. Effect of root exposure to - 8 and - 11C on M.26, MM.106, MM.111, M.7A, and M.7EMLA root survival and regrowth of 'Gravenstein' and 'Wealthy' apple scions.

\begin{tabular}{|c|c|c|c|c|}
\hline \multirow[b]{2}{*}{ Variable } & \multicolumn{2}{|c|}{ Root survival (\%) } & \multicolumn{2}{|c|}{$\begin{array}{c}\text { New growth } \\
{\left[\log _{10}(g+1)\right]}\end{array}$} \\
\hline & $-8 \mathrm{C}$ & $-11 \mathrm{C}$ & $-8 \mathrm{C}$ & $-11 C$ \\
\hline \multicolumn{5}{|l|}{ Rootstock (both scions) } \\
\hline M.26 & 89.3 & 53.9 & 1.082 & 1.119 \\
\hline MM.106 & 93.1 & 57.0 & 1.205 & 0.445 \\
\hline MM.111 & 92.0 & 77.7 & 1.219 & 0.960 \\
\hline M.7A & 92.9 & 38.4 & 1.167 & 0.819 \\
\hline M.7EMLA & 86.6 & 43.2 & 1.176 & 0.436 \\
\hline $\mathrm{SEM}^{\mathrm{z}}$ within temp & & & & \\
\hline$(\mathrm{n}=4, \mathrm{df}=17)$ & \multirow{2}{*}{\multicolumn{2}{|c|}{6.75}} & \multirow{2}{*}{\multicolumn{2}{|c|}{0.1193}} \\
\hline Scion (all rootstocks) & & & & \\
\hline Gravenstein & 91.3 & 58.0 & 1.262 & 1.077 \\
\hline Wealthy & 90.2 & 50.1 & 0.919 & 0.593 \\
\hline $\mathrm{SEM}^{2}$ within temp & \multirow{2}{*}{\multicolumn{2}{|c|}{4.27}} & & \\
\hline$(\mathrm{n}=10, \mathrm{df}=17)$ & & & \multicolumn{2}{|c|}{0.0754} \\
\hline
\end{tabular}

${ }^{2} \mathrm{SEM}=$ Standard error of mean. 
Table 2. Effect of trunk exposure to $-25 \mathrm{C}$ on 'Gravenstein' and 'Wealthy' apple bark and wood survival estimations and regrowth across all rootstock combinations.

\begin{tabular}{|c|c|c|c|c|c|}
\hline \multirow[b]{3}{*}{ Variable } & \multicolumn{4}{|c|}{ Survival index (\%) } & \multirow{3}{*}{$\begin{array}{r}\text { New growth } \\
{\left[\log _{10}(\mathrm{~g}+1)\right.}\end{array}$} \\
\hline & \multicolumn{2}{|c|}{ Trunk } & \multicolumn{2}{|c|}{ Laterals } & \\
\hline & Bark & Wood & Bark & Wood & \\
\hline \multicolumn{6}{|l|}{ Scion (all rootstocks) } \\
\hline Gravenstein & 81.4 & 63.9 & 63.1 & 34.4 & 1.249 \\
\hline Wealthy & 79.9 & 68.6 & 61.2 & 64.5 & 1.304 \\
\hline $\operatorname{SEM}^{\mathrm{z}}(\mathrm{n}=10, \mathrm{df}=16)$ & 2.73 & 3.88 & 2.81 & 7.55 & 0.0337 \\
\hline \multicolumn{6}{|l|}{ Rootstock (both scions) } \\
\hline M.26 & 89.6 & 64.9 & 64.7 & 48.9 & 1.373 \\
\hline MM.106 & 85.8 & 72.0 & 73.4 & 65.2 & 1.179 \\
\hline MM.111 & 86.0 & 69.2 & 58.3 & 54.4 & 1.334 \\
\hline M.7A & 77.0 & 75.3 & 71.7 & 50.0 & 1.296 \\
\hline M.7EMLA & 64.7 & 49.7 & 42.5 & 28.9 & 1.199 \\
\hline $\operatorname{SEM}^{2}(n=4, d f=16)$ & 4.31 & 6.13 & 4.44 & 11.94 & 0.0533 \\
\hline
\end{tabular}

${ }^{z} \mathrm{SEM}=$ Standard error of mean.

Table 3. Effect of trunk exposure to $-35 \mathrm{C}$ on 'Gravenstein' and 'Wealthy' apple bark and wood survival estimations and regrowth across all rootstock combinations.

\begin{tabular}{|c|c|c|c|c|c|}
\hline \multirow[b]{3}{*}{ Variable } & \multicolumn{4}{|c|}{ Survival index (\%) } & \multirow{3}{*}{$\begin{array}{c}\text { New growth } \\
{\left[\log _{10}(g+1)\right]}\end{array}$} \\
\hline & \multicolumn{2}{|c|}{ Trunk } & \multicolumn{2}{|c|}{ Laterals } & \\
\hline & Bark & Wood & Bark & Wood & \\
\hline \multicolumn{6}{|l|}{ Scion (all rootstocks) } \\
\hline Gravenstein & 14.2 & 12.1 & 0.0 & 0.0 & 0.163 \\
\hline Wealthy & 40.0 & 16.0 & 10.6 & 0.0 & 1.214 \\
\hline $\mathrm{SEM}^{\mathrm{z}}(\mathrm{n}=10, \mathrm{df}=16)$ & 1.67 & 2.16 & 1.98 & 0.00 & 0.0866 \\
\hline \multicolumn{6}{|l|}{ Rootstock (both scions) } \\
\hline M.26 & 23.1 & 15 & 32.0 & 0.0 & 0.811 \\
\hline MM.106 & 32.2 & 12.8 & 9.5 & 0.0 & 0.712 \\
\hline MM.111 & 28.6 & 12.7 & 4.6 & 0.0 & 0.788 \\
\hline M.7A & 25.0 & 18.2 & 6.1 & 0.0 & 0.546 \\
\hline M.7EMLA & 26.5 & 11.4 & 4.3 & 0.0 & 0.585 \\
\hline $\operatorname{SEM}^{\mathrm{z}}(\mathrm{n}=4, \mathrm{df}=16)$ & 2.64 & 3.41 & 3.13 & 0.00 & 0.1370 \\
\hline
\end{tabular}

${ }^{2} \mathrm{SEM}=$ Standard error of mean.

Root survival in root-frozen trees was evaluated by separating roots exhibiting browning from those showing no damage. Free water was removed and fresh weights were measured. Survival was expressed as the percentage of roots undamaged.

Trunk survival in trees with frozen tops was determined by making several longitudinal cuts from the extent of terminal growth to the soil line. This exposed thin columns of phloem and cambial tissue (bark) on either side of the apex of the cut, which exposed the outer xylem tissue (wood). For bark and wood, the length of trunk showing no damage (no discoloration), partial damage (light to medium brown), or severe damage (dark brown to black) was measured. Trunks and laterals were examined separately. This method of assessing damage is similar to that described by Yadava et al. (1984). Survival was expressed in terms of a survival index, calculated as [(percentage of length undamaged $)+0.5 \times$ (percentage of length partially damaged)], with a range from $0 \%$ (no survival) to $100 \%$ (complete survival).

Nondestructive evaluation. Specimens from the other paired replicate were grown in a greenhouse until the following November. Regrowth of each tree was determined by removing all new growth and recording the total fresh weight, the number of new shoots, and the combined length of new shoots.

Statistical analysis. Analysis of variance were calculated according to a replicated splitplot design, with replicates $\mathrm{x}$ temperature after exposure to - 8C, was greater than that of 'Wealthy' scions by $0.343 \log _{10} \mathrm{~g}$ and may be attributed, in part, to differences in scion vigor. After root exposure to - $11 \mathrm{C}$, the difference in regrowth was $0.484 \log$, $\mathrm{g}$, larger by $0.141(\mathrm{SD}=0.107)$ on the logtransformed scale. Although this difference was only significant at $P=0.10$ (one tailed test), it was consistent with the root survival measurements and may, therefore, indicate a scion effect on root hardiness.

Trunk hardiness. The upper parts of Tables 2 and 3 compare the intrinsic hardiness of the two cultivars. At -25C (Table 2), there were no significant differences in survival of trunk bark, trunk wood, or lateral bark, while lateral wood survival was higher $(P<0.05)$ for 'Wealthy' than for 'Gravenstein'. Weight of new growth was similar for 'Gravenstein' and 'Wealthy'. After exposure to -35C (Table 3), survival of both trunk and lateral bark was higher for 'Wealthy' than for 'Gravenstein', and these differences were reflected in more regrowth. There were no significant differences in trunk wood or lateral wood survival between the two varieties. These results confirm the greater bark hardiness of 'Wealthy'.

The lower parts of Tables 2 and 3 compare the hardiness of both scions on the various rootstocks. After trunk exposure to $-25 \mathrm{C}$ (Table 2), the survival indices differed for all tissues examined; scions on M.7EMLA consistently showed the lowest tissue survival. Regrowth of scions on M.7EMLA was also less than on M.26 and MM.111. At - 35C (Table 3), tissue survival in the scions was low, with no significant differences among rootstocks. There was a trend toward less regrowth $(\boldsymbol{P}=0.12)$ with scions on the rootstocks M.7A and M.7EMLA than on the others. The consistency of these results with the root survival study indicates that the rootstock may have an effect on trunk hardiness, although we recognize that further tests would be needed to confirm these effects.

Methods compared. In addition to defining hardiness and its potential transfer to the rootstock or scion, this experiment was designed to provide a preliminary comparison of two methods of evaluating cold damage to the trunk or the roots of apple trees. For root exposure (Table 1), the methods had correlations of 0.74 and $0.81(n=20)$. For trunk exposures (Tables 2 and 3), correlation coefficients for survival of trunk bark, trunk wood, lateral bark, and lateral wood with weight of regrowth were $0.81,0.58,0.68$, and 0.50 , respectively. Weight of new growth showed a higher correlation with determinations on bark than on wood, and trunk bark survival was a better indicator of new growth potential than was lateral bark survival. For the other methods of measuring regrowth, i.e., combined length of new terminals and number of new terminals, correlation with measurements of weight of new growth over root and trunk exposures were 0.96 and 0.74 , respectively $(n=40)$. Therefore, length of laterals could be used in place of their weight. 
The regrowth method of evaluating cold stress in apple roots and trunks requires less labor and is more objective than tissue examination. Regrowth measurements could be useful as a method for screening a large number of breeding progeny. As a measure of recovery, weighing new growth is simple and quick. Using length of new regrowth as the indicator of scion hardiness, however, would allow second exposure and other longer-term studies on trees with varying degrees of cold damage.

\section{Literature Cited}

Chandler, C.K. and D.C. Ferree. 1990. The winter of 1983-84: A test winter for Ohio's fruit crops. Fruit crops 1990: A summary of research. Res. Circ. 297, The Ohio State Univ., Columbus.

Cummins, J.N. and H.S. Aldwinckle. 1974. Breeding apple rootstocks. HortScience 9:367372.
Czynczyk A. 1979. Effect of M.9, Bud., 9 and M.26 rootstocks on growth, fruitng and frost resistance of apple trees. Fruit Sci. Rpt. 6:143151.

Embree, C.G. 1984. An assessment and illustration of winter injury to selected apple cultivars in Nova Scotia, 1980-1981. Fruit Var. J. 38:813.

Embree, C.G. 1988. Apple rootstock cold hardiness evaluation. Compact Fruit Tree 21:99-105.

Ferree, D.C. and R. Perry. 1988. Rootstock evaluation through the NC-140 project. HortScience 23:102-104.

Filewicz, W.L. and I. Modlibowski. 1941. The influence of the scion maturity on the resistance of the roots against frost. Proc. Amer. Soc. Hort. Sci. 38:348-352.

Quamme, H.A. and R.T. Brownlee. 1989. Observation of winter injury to the roots of apple trees associated with sprinkler irrigation pattern. Can. J. Plant Sci. 69:617-621.

Simons, R., R. Hayden, P. Domoto, F. Morrison, G. Brown, W. Lord, R. Perry, M. Wamumd, D. Ferree, and E. Stang. 1986. NC-140 1976 cooperative apple interstem planting. Fruit Var. J. 40:108-115.

Stuart, N.W. 1937. Cold hardiness of some apple understocks and the reciprocal influence of stock and scion on hardiness. Proc. Amer. Soc. Hort. Sci. 35:386-389.

Tukey, H.B. and K.D. Brase. 1939. The behaviour of Malling apple rootstocks in the nursery. Proc. Amer. Soc. Hort. Sci. 36:113-115.

Warmund, M.R. and J.V. Slater. 1988. Hardiness of apple and peach trees in the NC-140 rootstock trials. Fruit Var. J. 42:20-24.

Westwood, M.N. 1970. Rootstock-scion relationships in hardiness of deciduous fruit trees. HortScience 5:418-424.

Wildung, D.K., C.J. Weiser, and H.H. Pellett. 1973. Cold hardiness of Malling clonal apple rootstocks under different conditions of winter soil cover. Can. J. Plant Sci. 53:323-329.

Yadava, U.L., S.L. Doud, and D.J. Weaver. 1984. Rating scales to assess cold injury and bacterial canker development in peach trees in the field. HortScience 19:645-648 